\title{
2021 APSA Council Nominations
}

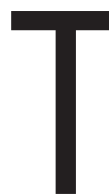

The APSA Nominating Committee is pleased to announce its 2021 nominees for APSA Council. Each has agreed to serve if elected. The call for nominations was circulated among the membership, and outreach specifically to APSA committees and organized sections was conducted. The committee made its decisions after careful deliberation and consideration for the diversity of the field and the varied interests of political scientists. The candidates will be put to a vote by the full membership via electronic ballot in August. APSA also accepts nominees by petition. The deadline for submitting nominees by petition was June 18 . Additional information about APSA elections, including instructions for submitting nominees by petition, is available at https://www.apsanet. org/ABOUT/Governance/Elections.

The 2020-2021 nominating committee is Stacie Goddard, Wellesley College (chair); David Darmofal, University of South Carolina; Rebecca Glazier, University of Arkansas at Little Rock; Sara Wallace Goodman, University of California, Irvine; Gabe Sanchez, University of New Mexico; and Kevin Scott, Bureau of Justice Statistics.

\section{PRESIDENT-ELECT (2021-2022)}

\section{Lisa Martin, University of Wisconsin-Madison}

Lisa L. Martin is professor of political science and Associate Dean of Graduate Education at the University of Wisconsin-Madison. Her work focuses primarily on international institutions, international political economy, and international cooperation.

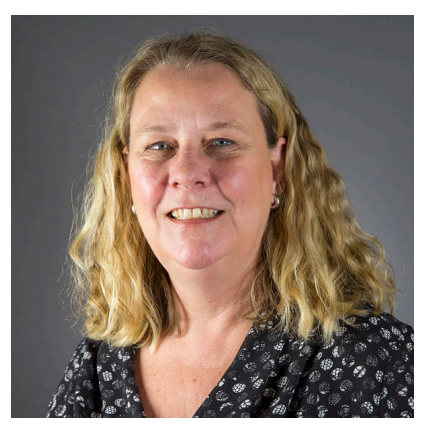

Statement of views: The discipline of political science combines rigorous theory and empirics with a commitment to understanding political dynamics throughout American society and the world. It thus has a vibrant internal dialogue, combined with engagement with practitioners and the broader society. The American Political Science Association, through its conferences, publications, awards, and organizing activities, plays a vital role in encouraging and structuring both these internal and external dialogues. In all of my service activities, I have been committed to the pursuit of excellence, inclusion, mutual respect, and transparency. I would bring these same core values to my position in the asso- ciation. Substantively, I will mobilize resources to develop plans for improving mentoring in the profession, including a focus on addressing hostile and intimidating behavior.

\section{VICE PRESIDENTS (2021-2022)}

\section{Amrita Basu, Amherst College}

Amrita Basu is the Paino Professor of Political Science, and Sexuality, Women's and Gender Studies at Amherst College. Her scholarship has focused on women's political activism, women's movements, and religious nationalism in India.

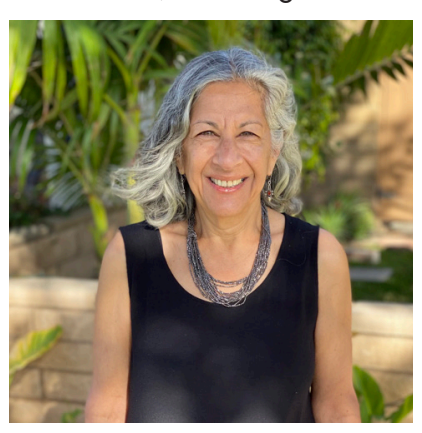

Statement of views: If elected vice president of APSA, my work would be guided by four priorities. First, I would seek to strengthen and extend recent efforts of the association to sponsor research on racial and gender inequities in our discipline and in the wider society, as well as to achieve greater diversity and inclusion in graduate admissions and in faculty recruitment and retention. My second priority is to fortify APSA's role in fostering an international scholarly community by creating and strengthening partnerships with research programs in the global South. My third priority, which reflects my experience of teaching at a liberal arts college, would be to encourage scholarly collaboration between undergraduate students and faculty and between political science and other disciplines. Fourth, I would support public facing scholarship which addresses issues of current political signifcance. Animating these priorities is my commitment to cultivating knowledge and institutional practices that advance more just and equitable practices within and beyond our discipline.

\section{Juan "Carlos" Huerta, Texas A\&M University, Corpus Christi}

Juan "Carlos" Huerta is professor of political science at Texas A\&M University, Corpus Christi. He joined the faculty in 1995 and led the university's nationally recognized First-Year Learning Communities Program (2003-2016).

Statement of views: As a vice president of the APSA, my overriding goal is guiding the association, in an inclusive manner, as we strengthen our discipline. The foundation is an undergraduate major that helps all our students find success in 


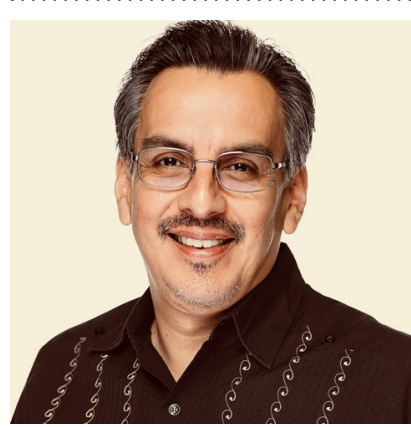

a wide variety of careers and post-graduate study. With a robust major we can foster an inclusive recruitment process to identify the next generation of graduate students. I will work with the association on graduate education as we inclusively prepare future PhDs to work in the wide range of institutions. A final goal is inclusive professional development for professors in teaching and research.

During my time on Council (2012-14) I worked towards these goals by advocating for the establishment of the Committee on the Status of Community Colleges in the Profession. Furthermore, I worked to give a voice to underrepresented faculty, including faculty of color and faculty who work at institutions primarily focused on undergraduate education. A major emphasis of my academic career has been directed towards promoting teaching and learning in higher education-especially for underrepresented students and students of color. Political science has so much to offer and I want to work to help us reach new heights.

\section{Mark E. Warren, University of British Columbia}

Mark E. Warren holds the Harold and Dorrie Merilees Chair for the Study of Democracy at the University of British Columbia. He was previously professor of political science at Georgetown University.

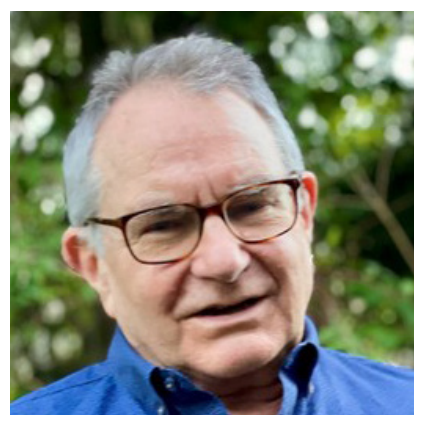

Statement of views: I am deeply honored to be nominated to serve as a vice president of the APSA. A member since I was a graduate student, I've served on the APSA Council, chaired the Foundations of Political Theory Section, and organized APSA Annual Meeting political theory sections a number of times. I've been impressed with the APSA's ability to incorporate and serve the very diverse interests within political science, to grow with the discipline, to lead diversity and inclusion initiatives, to support excellence in teaching and research across a wide array of institutions and circumstances, and to raise the public profile and impact of political science. In addition to helping the APSA to continue to build on these strengths, we should continue to find ways of addressing urgent and ongoing existential threats to democracy, justice, and good government, as well as potentially catastrophic failures of collective action, including the climate crisis. It will be especially important to continue to our dialogue about how the APSA can serve these important social and political missions while remaining an inclusive and pluralistic professional organization.

\section{APSA COUNCIL (2021-2024)}

\section{Khalilah L. Brown-Dean, Quinnipiac University}

Khalilah L. Brown-Dean is professor of political science and Associate Provost for Faculty Affairs at Quinnipiac University. She holds a BA in government from The University of Virginia and a $\mathrm{PhD}$ in political science from The Ohio State University.

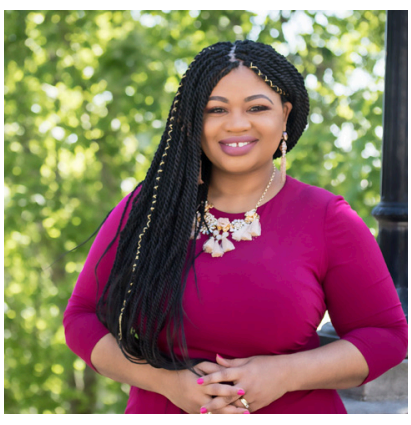

Statement of views: I am honored to be nominated for this opportunity to serve. I gave my first annual meeting presentation as an undergraduate fellow of the Ralph Bunche Summer Institute and have been active with the association ever since. Bunche introduced me to the importance of building dedicated pipelines and programmatic commitments that create myriad opportunities for scholars trained in political science. As a member of the Council I will work to deepen our investment in the recruitment, retention, and promotion of scholars from diverse backgrounds. The ever-changing landscape of both politics and higher education demand that we evaluate our approaches to this evolution. How do we best prepare our members to successfully navigate this terrain while remaining rooted in the positive traditions that have sustained APSA for over 118 years? How do we make commitment investments in the long-term success of our members and partners that includes sustained interest in those working within and beyond the academy? How do the innovations made in response to COVID-19 guide how we will approach future conferences and commitments? Finally, how do we emphasize the "scholar" in public scholarship to empower members to leverage their expertise to enhance awareness, civic engagement, and meaningful change? I look forward to exploring these possibilities as a member of the Council.

\section{Scott Desposato, University of California, San Diego}

Scott Desposato is professor of political science and Simón Bolívar Chair of Latin American Studies at the University of California, San Diego. He co-chaired APSA's Ad Hoc Committee on Human Subjects Research, which drafted the new Principles and Guidance to support ethical political science research.

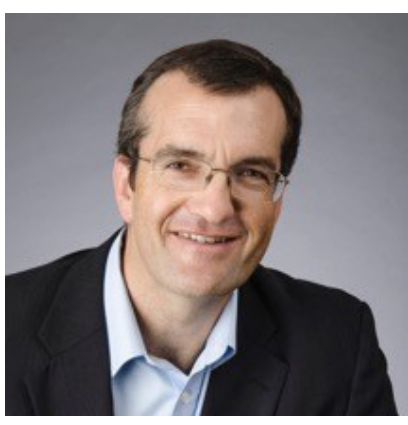

Statement of views: I am honored to be nominated for the APSA Council. My priorities include keeping costs low and making APSA membership and conferences affordable, con-

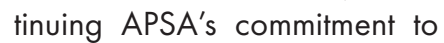
intellectual and methodological diversity, promoting ethical and transparent research that respects the subjects and societies we study, and supporting the inclusion of all underrepresented groups. I am also deeply concerned with the erosion of democratic institutions in many countries and believe that political scientists and APSA need to contribute their voices and research in defense of democracy.

\section{Raymond Foxworth, First Nations Development Institute}

Raymond Foxworth is vice president of First Nations Development Institute and a visiting scholar at the University of New Mexico (2021-2022). At First Nations, Raymond conducts re- 
search on barriers and opportunities to Native American economic and community development.

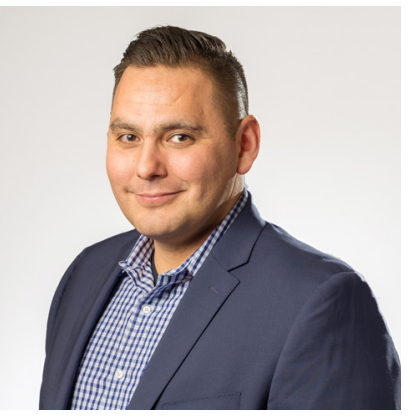

Statement of views: I am extremely honored to be nominated to serve on the APSA Council. If elected to serve on the APSA Council, I would continue to champion ways to make the discipline more inclusivefor scholars and for consumers of our research. I would also contribute to ongoing diversity, equity and inclusion efforts of APSA, with a focus on providing a welcoming environment for diverse voices and scholarship to be heard in our field. Finally, I would actively work to promote more community-engaged scholarship in the field.

I have worked with APSA representatives and other scholars to identify barriers to recruitment of Indigenous scholars in the field of political science. As a member of the APSA Council, I would continue to champion this work, with a goal of making our disciple more diverse, equitable and inclusive. Secondly, training as a political scientist and work experience in non-profits and policy has equipped me with skills and tools to be a valuable research partner with communities, tackling real-world issues that impact the lives of average citizens. As an APSA Council member, I would continue to advocate for ways that political scientists can use their skills and training to solve real-world problems that are important to communities across the globe.

\section{Terri E. Givens, Brighter Higher Ed}

Terri E. Givens studied international relations at Stanford University and completed her PhD in political science at UCLA in 2000. She became provost at Menlo College in 2015, and in 2019 founded Brighter Higher Ed, a platform for professional development for higher education leaders.

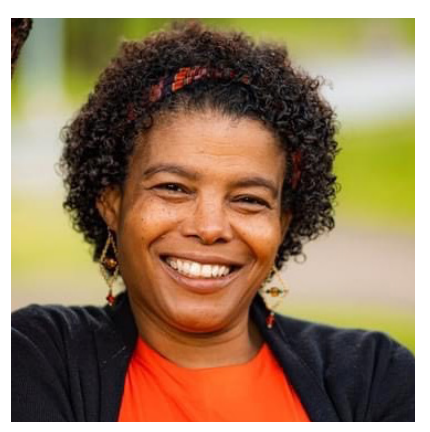

Statement of views: Higher education is facing ongoing political and financial challenges that are undermining support for tenured faculty, their research, and leaving our students with high levels of debt. In the wake of the pandemic, political science will need to monitor broader trends and ways that developments in online/ remote learning and educational technology are impacting students and faculty. Changing demographics will impact the discipline in a variety of ways, but we need to be more proactive in supporting diversity of all kinds and creating a discipline that is preparing our students to be global citizens, understanding the inequalities that our society must address. My experience as a provost and leader will provide a unique perspective on these issues. I also believe that political scientists need to be more aware of the history of our discipline, including the role of leaders like Ralph Bunch and Merze Tate, to ensure that our students understand the origins of the discipline and how it impacts political science today.

\section{Eileen M. Hunt, University of Notre Dame}

Eileen M. Hunt is a political theorist and professor of political science at Notre Dame. Her scholarly interests cover modern political thought, feminism, the family, rights, ethics of technology, and philosophy and literature.

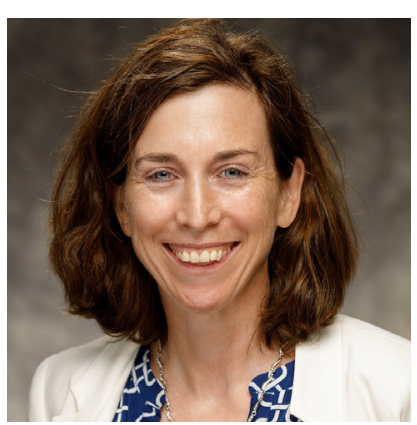

Statement of views: As a political theorist and historian of political thought, I have been an advocate of methodological pluralism who considers constitutional democracy and equal rights to be governing concepts of the discipline of political science. It is crucial to train the next generation of political theorists to substantively engage with the other subfields in political science, in order to make clear the value of political theory for the wider discipline, and to better understand theories and practices of democracy and rights. Historically, the most creative and important work in political science has been done in a way that is radically interdisciplinary. The future of the APSA is rooted in its professional origins in the early twentieth century, with the rise of the social sciences alongside the modern humanistic disciplines of history, literature and languages, and philosophy. Substantively, political science and political theory have never mattered more than in the crisis-driven pandemic and presidential election year of 2020 to 2021. Going forward, political science and political theory must be ready to take up the task of clarifying why the study of ideas and practices of equal rights and democratic constitutionalism matter not only for the advancement of knowledge across disciplines, but also for the political goal of securing freedom and justice for each and all.

\section{Mary McHugh, Merrimack College}

Mary McHugh is the Executive Director of Civic and Community Engagement in the Stevens Service Learning Center at Merrimack College. As a member of the college's political science department for over 27 years, she has taught a variety of courses in US politics and political institutions.

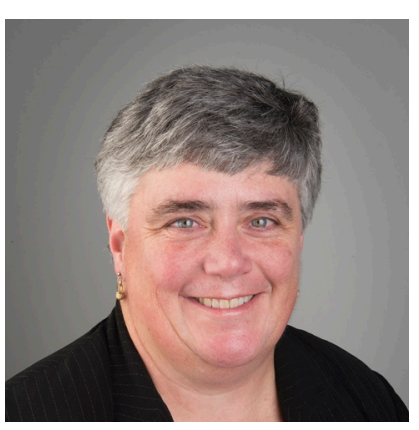

Statement of views: It is an honor to be nominated to serve on the APSA Council. Even though I have been a member of APSA for over 25 years, as someone who has worked at a smaller liberal arts institution, I never expected to be in this position, because of the type of institution where I work. As such, if elected, I would like to focus my term on making APSA more relevant and welcoming to the entire membership. As higher education faces the longterm effects of COVID-19 and a fragile political environment, the association needs to prioritize and work collaboratively with members who come from a wide array of colleges, universities, and institutions outside of academia, all of which are venues where political scientists work. Our younger members and colleagues are also facing a very different job market than in the 
past. We should seek ways to promote affordable professional development opportunities, create additional time and space to talk about quality teaching and learning, and continue discussions of non-traditional career paths. Additionally, we need to integrate and increase the work we are doing in civic and political engagement more fully into all areas of the discipline as we respond to political events throughout the country and the world. Thus, I would like to focus my time and efforts on the Council on insuring that these areas of the discipline and the membership are represented within the organization.

\section{Sara McLaughlin Mitchell, University of lowa}

Sara McLaughlin Mitchell is the F. Wendell Miller Professor of Political Science at the University of lowa. She received her PhD in political science at Michigan State University in 1997 and her BS degree in economics and political science at lowa State University in 1991.

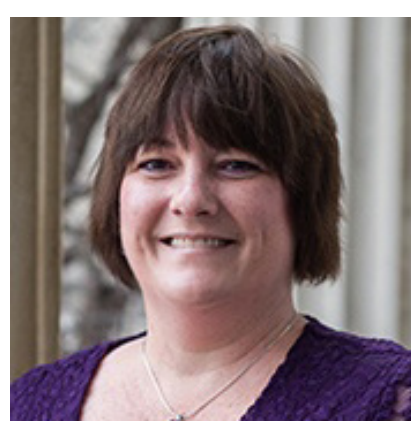

Statement of views: I am very honored to be nominated for the APSA Council. As an APSA member for more than 25 years (yikes!), I have worked to promote gender equality in the organization and discipline more generally. I coauthored several articles with Vicki (Hesli) Claypool on gender disparities in rank, service loads, and salaries using APSA member survey data. I also worked with Michelle Dion and Jane Sumner to analyze gender gaps in citations and to understand why women are underrepresented in journals affiliated with APSA sections compared to section membership representation. I also co-founded the Journeys in World Politics program with Kelly Kadera to mentor women in international relations. I have been actively involved with the Visions in Methodology conferences to support women in political methodology. I also worked with leaders of the APSA political methodology section to improve gender representation and mentoring in the section. I served in various leadership positions in the International Studies Association to help address gender and diversity issues, and if elected as an APSA council member, I will bring this same energy to gender and diversity, equity, and inclusion issues in our association.

\section{Costas Panagopoulos, Northeastern University}

Costas Panagopoulos is professor of political science and chair of the Department of Political Science in the College of Social Sciences and Humanities at Northeastern University, where he was previously Director of Big Data and Quantitative Initiatives.

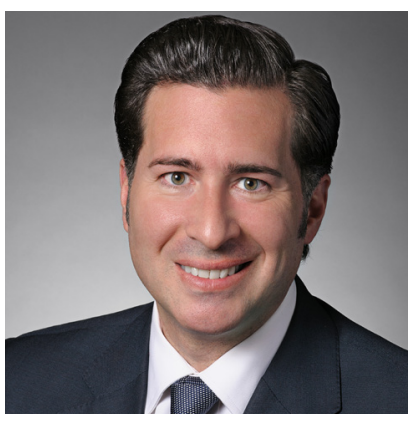

Statement of views: I am honored to be nominated to serve on the APSA Council. This is a crucial time for our discipline and our association. While we are confronted simultaneously with many challenges, these also present opportunities for our community to reinvigorate our efforts to promote social justice, diversity, equity and inclusion, to combat misinformation and shed light on truth in the political world, and to engage broadly and energetically with colleagues both within and outside of the academy. Robust dialogue and exchange between scholars, journalists, policymakers and elected officials are vital to sustaining, extending and strengthening the relevance and applicability of our scholarship and to solving the many, vexing social and political challenges we face. I believe the best solutions will emerge when ideas from our diverse perspectives are encouraged and debated, and APSA can play a central role in providing platforms and opportunities for such exchanges. There has arguably never been a time in APSA's 122-year history when the need to leverage our expertise and to showcase the diverse voices of our discipline have been more essential, especially to help preserve and advance basic democratic principles and political institutions. I am committed to advocating for these priorities as a member of the Council.

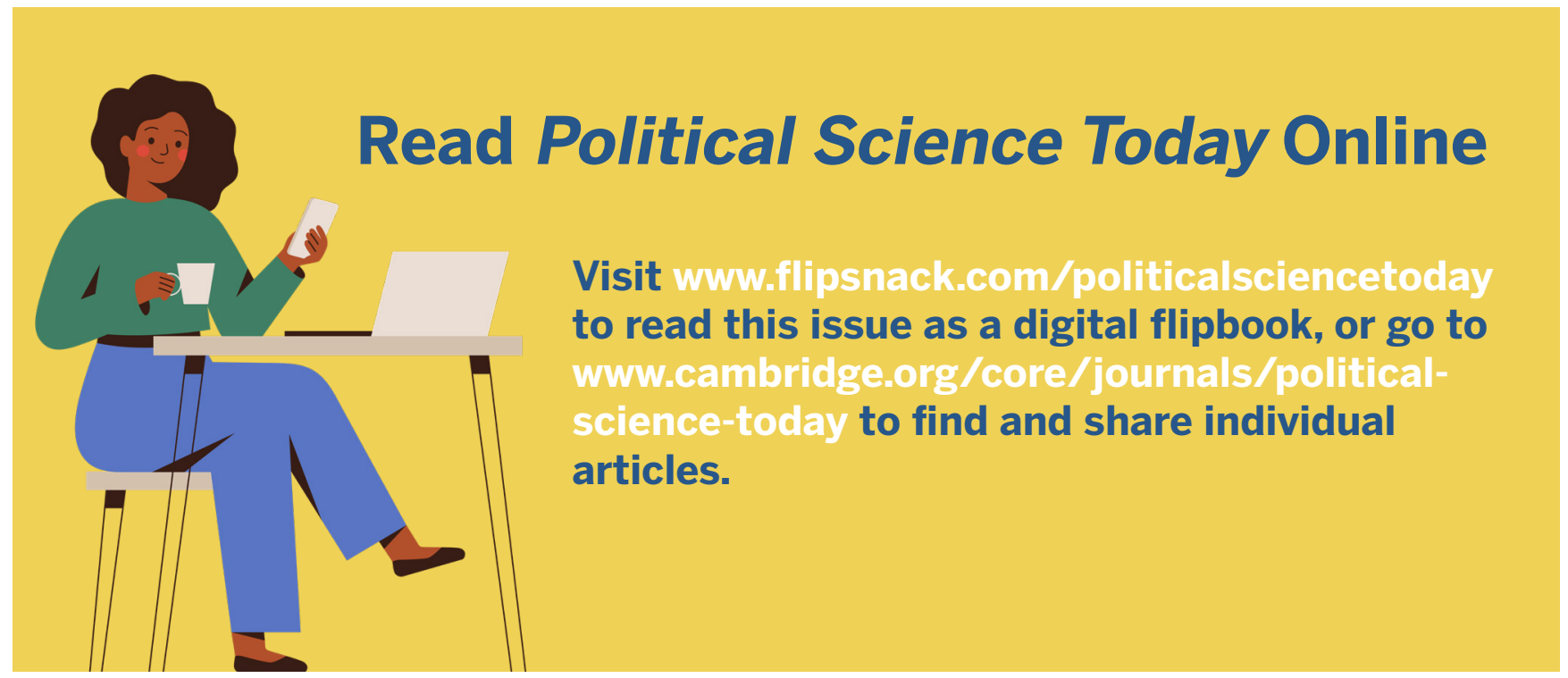

